\title{
Membangun Masyarakat Religius melalui Pembudayaan Amaliah Islam Nusantara pada Masyarakat Transisi
}

\author{
Ainul Yakin
}

Universitas Nurul Jadid, Probolinggo

\{yakin4255@gmail.com\}

Submission: 2021-01-27 Received: 2021-04-23 Published: 2021-04-30

\begin{abstract}
Keywords:
Abstract. Wisma Pengadengan Sejahtera (WPS) residents tend to

Religious

be individualistic, rigid, there is a gap between one resident and

Transiton,

another. Communication and communication opportunities

Culture, between residents are relative, even among those who do not

Partcipatory, WPS know each other. In addition, there are very few places of worship Housing compared to the number of residents. So that the media to get to know each other and communication is increasingly limited. Residents of the WPS housing estate, who are migrants, can be said to be moving around. They experience a change from a society to an entirely new society. Among them are those who come from rural areas who have experienced a transition to urban habits, and have experienced a shift in their livelihoods from agricultural labor to the industrial and government sectors. On average they work at PLTU, IPMOMI Paiton, PT Sampoerna, Civil Servants and so on. Open access to roads and a relatively high educational background provides opportunities for change towards progress. But on the other hand, their professionalism covertly inhibits the sense of religion and solidarity among citizens. They can even say they are spiritually dry. So it requires a more religious, religious and friendly nuance of life. In the midst of such a complex community life, the solution offered by PKM in that environment is by forming recitation groups and religious activities with a participatory approach. PKM strives to build a religious society through the cultivation of the Islamic practices of the Archipelago, the construction of religious facilities and Islamic education. As a result, residents of the WPS housing program currently have three recitation groups, Madrasah Diniyah and three religious facilities. This cannot be separated from the cooperation and hard work of the citizens through the participatory approach in PKM.
\end{abstract}


Katakunci:

Transisi Religius, Pembudayaan, Partipatoris, Perumahan WPS
Abstrak. Penguni Wisma Pengadengan Sejahtera (WPS) cenderung individualis, kaku, ada gap antar satu warga dengan warga lain. Kesempatan interaksi dan komunikasi antar warga relatif sulit, bahkan di antara mereka ada yang tidak saling mengenal. Selain itu, sarana ibadah yang ada sangat minim dibandingkan jumlah penghuninya. Sehingga media untuk saling mengenal dan komunikasi pun makin terbatas. Warga perumahan WPS yang natabene masyarakat pendatang, bisa dibilang masyarakat transisi. Mereka mengalami perubahan dari suatu masyarakat ke masyarakat yang sama sekali baru. Di anatra mereka ada yang berasal dari pedesaan yang mengalami transisi ke arah kebiasaan kota, dan mengalami pergeseran pencaharian dari tenaga kerja pertanian ke sektor industri dan pemerintahan. Rata-rata mereka berkerja di PLTU, IPMOMI Paiton, PT Sampoerna, Pegawai Negeri Sipil dan lain sebagainya. Akses yang terbuka dengan jalan raya dan latar belakang pendidikan yang realtif tinggi memberi peluang adanya perubahan ke arah kemajuan. Namun pada sisi lain, profesionalitas mereka secara terselubung menghambat rasa keagamaan dan solidaritas di atara warga. Bahkan dapa dibilang mereka kering spiritual. Sehingga membutuhkan adanya nuanasa kehidupan yang lebih agamis, religius dan guyub. Di tengah-tengah kehidupan masyarakat yang kompleks semacam ini, solusi yang ditawarkan PKM di lingkungan tersebut dengan membentuk kelompok pengajian dan kegiatan-kegiatan keagamaan dengan pendekatan partisipatoris. PKM mengupayakan untuk membangun masyarakat religius melalui pembudayan amaliah Islam Nusantara, pembangunan sarana ibadah dan pendidikan Islam. Walhasil saat ini warga perumahan WPS sudah memiliki kelompok pengajian sebanyak tiga kelompok, Madrasah Diniyah dan tiga sarana ibadah. Hal ini tidak lepas dari kerja sama dan kerja keras warga melalui pendekatan partisipatoris dalam PKM

\section{Pendahuluan}

Kompleks perumahan Wisma Pengadengan Sejahtera (WPS) secara geografis terletak di kawasan pinggiran kota Kraksaan, yang beririsan dengan pantai utara. Secara administratif Perumahan WPS berada di desa Kebonagung Kraksaan Kabupaten Probolinggo. Perumahan tersebut tergolong baru, dibangun sejak tahun 2007 tahun. Dalam perjalanan waktu hingga tahun 2020, developer terus melakukan pengembangan kompleks, yang semula penduduknya hanya berkisar 100 KK, tapi saat ini sedah 
mencapai 260 KK. Secara umum penduduk perumahan WPS beragama Islam. Sekalipun ada sekitar 10 KK yang beragama Kristen.

Warga perumahan WPS yang natabene masyarakat pendatang, bisa dibilang masyarakat transisi. Mereka mengalami perubahan dari suatu masyarakat ke masyarakat yang sama sekali baru. Di anatra mereka ada yang berasal dari pedesaan yang mengalami transisi ke arah kebiasaan kota, dan mengalami pergeseran pencaharian dari tenaga kerja dari pertanian, dan mulai masuk ke sektor industry. Rata-rata mereka berkerja di PLTU, IPMOMI Paiton, PT Sampoerna, di sector pemerintahan dan lain sebagainya.

Mayoritas warga WPS beragama Islam. Sekalipun beragama Islam, aliran keagamaan yang berkembang di perumahan cukup beragam, ada yang berafiliasi dengan Nahdlatul Ulama (NU), Muhammadiyah, Eks Hizbut Tahrir, dan Salafiy. Keragaman tersebut membuat hubungan antara warga relatif tegang dan bahkan ada konflik secara terselubung dan persaingan antara aliran. Selain itu, profesi warga yang beragam juga berkontribusi lahirnya kehidupan warga WPS yang dinamis. Sementara media dan fasilitas umum seperti rumah ibadah cukup minim untuk mewadahi kegaiatan wagra. Sehingga meraka praktis "kering kegiatan keagamaan". Minimnya kegiatan dan faslilitas ibadah sebagai media keagamaan dan komunikasi warga masyarakat WPS memicu rendahnya kesadaran koletif yang pada ujunganya kesadaran keagamaan pun relatif rendah.

$\mathrm{Hal}$ di atas dapat dipahami mengingat warganya yang terbilang baru, dan masa transisi dari lingkungan sebelumnya menuju lingkungan yang sama sekali baru. Sehingga dalam keseharian mereka membutuhkan adaptasi karena perbedaan latar belakang sosial, budaya bahkan paham keagamaan. Pada masyarakat tarnsisi semacam ini rentan terjadinya konflik inters dan konflik terselubung, yang kadangkala seringkali terjadi miss understanding dan miss komunikasi di antara mereka. Sehingga yang tampil ke permukaan seakan-akan warga WPS individualis dan egois cenderung tertutup.

Sementara itu, hasil survei lembaga think tank asal Amerika Serikat, Pew Research Center baru-baru ini merilis Indonesia sebagai negara dengan penduduk paling religius di dunia. Hasil survei internasional tersebut membuat Indonesia unggul dari 32 negara lainnya. Hasil survei tersebut menunjukkan bahwa masyarakat Indoensia adalah masyarakat yang religius. Sekalipun di sejumlah daerah nilai religiusitas masyarakatnya mulai terkikis. Rendahnya kesadaran keagamaan senyatanya dilatarbelakangi banyak factor. 
Diantara factor tersebut adalah rendahnya pengetahuan agama, minimnya fasilitas ibadah, kesibukan warga dalam mencari mata pencaharian, atau karena minimnya actor yang menggerakkan kegiatan keagamaan.

Gerakan untuk mewujudkan masyarakat yang religisu dan menghidupkan tardisi Islam masyarakat tarnsisi semacam ini tentu tidak mudah. Sebab kesadaran kolektif adalah sebuah kata kunci penting untuk menjadikan masyarakat transisi tersebut lebih religius. Sebab secara ekonomi mereka sudah tidak terlalu bermasalah. Bedahalnya dengan masyarakat desa yang relative mengalami kesulitan dalam mata pencaharian sehari-harinya yag tidak pasti. Mereka lebih bergantung pada alam seperti menunggu musim penghujan bagi petani desa.

Tradisi amaliah Islam seperti tahlilan, yasinan, maulidan pada masyarakat Islam nusantara bukan hal yang baru. Masyarakat Indonesia telah memiliki bahkan menjalakan tradisi tersebut secara turun temurun. Hidupnya tradisi amaliah Islam nusantara mesti didukung dengan kesadaran religius masyarakat setempat. Masyarakat WPS sebagai Urban Community memiliki karakter sekaligus masalah yang berbeda dengan masyarakat pedesaan. Ada beberapa ciri yang menonjol pada masyarakat perumahan yaitu:

a. Kehidupan keagamaan mereka lebih rendah bila dibandingkan dengan kehidupan keagamaan di desa

b. Mereka pada umumnya dapat mengurus dirinya sendiri tanpa harus bergantung pada orang lain,

c. Ada kesulitan adaptasi dengan lingkungan baru karena penghuninya samasama pendatang,

d. Pembagian kerja di antara warga tegas dan mempunyai batas-batas yang nyata.

e. Kehidupan agamanya berkurang sebab biasanya hanya duniawi saja yang di kejarnya tanpa memikirkan kelak akhirat nanti

f. Cenderung hidup sendiri-sendiri dan kurang peka terhadap lingkungan tetangga sesama warga WPS

g. Perubahan-perubahan yang terjadi di WPS terlihat nyata sangat berpengaruh dari budaya luar dan lebih sering terkena dampak globalisasi.

h. Mereka sukar untuk disatukan, karena perbedaan politik dan agama, dengan pola pikiran rasional Pada umumnya merkea dapat mengurus dirinya sendiri tanpa bergantung pada orang lain.

i. Interaksi-interaksi yang terjadi lebih berdasarkan pada faktor kepentingan pribadi daripada kepentingan umum. 
j. Peralihan dan transisi dari masyarakat sebelumnya menjadi masyarakat kota.

Menghidupkan tardisi Islam lokal pada masyarakat transisi semacam ini tidaklah mudah. Konsep masyarakat religius yang menghargai ilmu pengetahuan dan teknologi, nilai-nilai agama, kejujuran, keadilan, amanah, kasih sayang, saling menghargai antar satu dengan yang lain, membutuhkan pendampingan dan pengawalan yang konkret. Tidak cukup dengan pendekatan konseptual dan teori. Oleh karenanya, PKM ini berusaha menghidupkan tradisi amaliah Islam loka melalui terobosan-terobosan yang sinergis, persuasif dan partisipatoris.

\section{Metode}

Metode yang digunakan PKM pada pengabdian ini adalah metode partisipatoris. Partisipasi sebenarnya berasal dari bahasa inggris yaitu dari kata "participation" yang dapat diartikan suatu kegiatan untuk membangkitkan perasaan dan diikutsertakan atau ambil bagian dalam kegiatan suatu organisasi. Sehubungan dengan partisipasi masyarakat dalam menghidupkan tradisi, partisipasi merupakan keterlibatan aktif masyarakat. Jadi partisipasi disini dapat berarti keterlibatan proses penentuan arah dari strategi dalam membangun masyarakat dapam rangka menghidupkan tradisi amaliah Islam Nusantara yang dilaksanakan PKM.

Dalam pelaksanaan PKM tentu dibutuhkan rangsangan dari masyarakat dalam keikutsertaannya memiliki motivasi. Menurut Simatupang (dalam Yuwono, 2001:124) memberikan beberapa rincian tentang partisipasi sebagai berikut :

a. Partisipasi berarti apa yang kita jalankan adalah bagian dari usaha bersama yang dijalankan bahu-membahu dengan saudara kita sebangsa dan setanah air untuk membangun masa depan bersama

b. Partisipasi berarti pula sebagai kerja untuk mencapai tujuan bersama diantara semua warga negara yang mempunyai latar belakang kepercayaan yang beraneka ragam dalam negara pancasila kita, atau dasar hak dan kewajiban yang sama untuk memberikan sumbangan demi terbinanya masa depan yang baru dari bangsa kita.

c. Partisipasi tidak hanya berarti mengambil bagian dalam pelaksanaanpelaksanaan, perencanaan pembangunan. Partisipasi berarti memberikan sumbangan agar dalam pengertian kita mengenai pembangunan kita nilai- 
nilai kemanusiaan dan cita-cita mengenai keadilan sosial tetap dijunjung tinggi.

d. Partisipasi dalam pembangunan berarti mendorong ke arah pembangunan yang serasi dengan martabat manusia. Keadilan sosial dan keadilan Nasional dan yang memelihara alam sebagai lingkungan hidup manusia juga untuk generasi yang akan datang.

Dalam konteks pembangunan, menurut Suryono (2001:124) partisipasi merupakan ikut sertanya masyarakat dalam pembangunan, ikut dalam kegiatan pembangunan dan ikut memanfaatkan dan menikmati hasil-hasil pembangunan.

\section{Hasil dan Pembahasan}

Dari hasil pendampingan dan partisipasi dalam menjalankan program kegiatan yang telah disepakati maka pertama-tama yang dilakukan sebagai upaya menghidupkan tradisi Islam nusantara adalah pertisipasi PKM dan warga dalam melakukan perencanaan, pengorganisasian, implementasi rencana, pengawasan dan pengontrolan. Maka didapatkan pula dinamika warga Perumahan yang ada untuk melakukan perubahan ke arah yang lebih baik dan terukur. Adanya program kerja dalam bentuk visi yang ingin dicapai sebagai perwujudan kepedulian kepada kegiatan keagamaan untuk menghidupkan tardisi keagamaan. Pendampingan dan pembinaan oleh PKM tentang pentingnya merumuskan tujuan yang ingin dicapai dan rencana misi dalam mewujudkan visi komunitas perumahan.

Namun demikian, pembinaan dan pendampingan untuk mewujudkan program kegiatan masih diperlukan pembimbingan dan keterlibatan dalam bentuk a). internalisasi pemahaman pentingnya menghidupkan tradisi keagamaan sebagai media silaturrahim antar warga b). membuat kalender kegiatan, c). membuat program kegiatan, d). membuat tahapan implementasi pelaksanaan program,e). merumuskan rencana tindak lanjut sebagai upaya perbaikan output sebagai hasil dari proses kegiatan.

Sumber Daya Manusia di perumahan WPS yang jadi sasaran dalam PKM ini, notabene adalah masyarakat dengan latarbelakang pendidikan umum dan profesional. Namun demikian, mereka hormat dan patuh pada konsep orang yang dipandang mumpuni dalam bidangnya khsusnya dalam bidang agama. Oleh karena itu, dengan kelebihan dan kekurangannya dipandang 
perlu untuk digerakkan melalui pendampingan dan partisipasi aktif yang terukur.

Keinginan warga perumahan WPS untuk mewujudkan masyarakat relegius mendapatkan dukungan dari warga yang lain karena dianggap sejalan dengan ajaran Islam. Mereka bersepakat masyarakat untuk saling menolong, menciptakan kedamaian dalam kehidupan sosial, ajaran agama dan amaliyah Islam Nusantara yang sudah lama mengakar.
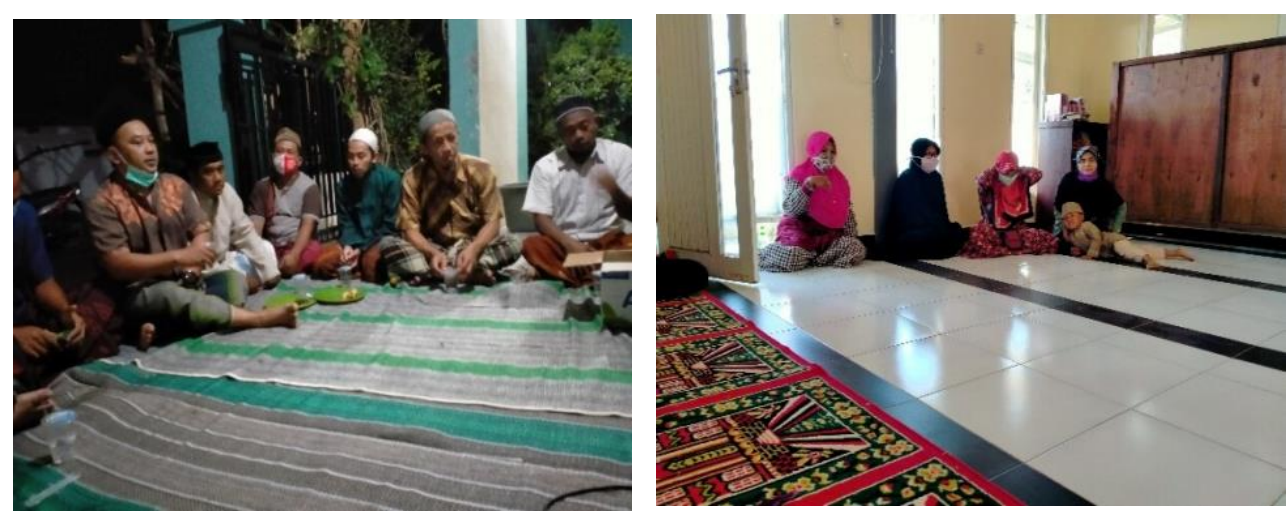

Gambar 1. Urun rembuk bersama warga untuk menyelenggarakan acara sarwa'an (yasinan dan tahlilan)

Prinsip-Prinsip yang disepakati antara warga khsusnya yang beragama Islam meliputi: pertingnya persaudaraan, keguyuban, persamaan, toleransi dan berembangnya nilai-nilai Islami Hal ini sesuai dengan firman Allah SWT: Kamu adalah umat yang terbaik yang dilahirkan untuk manusia, menyuruh pada yang ma'ruf, dan mencegah dari yang munkar, dan beriman kepada Allah. Sekiranya ahli kitab beriman, tentulah itu lebih baik bagi mereka; diantara mereka ada yang beriman, dan kebanyakan mereka adalah orangorang yang fasik. (QS Ali Imran [3]: 110).

Dalam prinsip persaudaraan mengingatkan pada kejadian manusia yang berasal dari sumber yang sama, baik laki-laki maupun perempuan (Q 49:10). Di ayat tersebut dijelaskan Nabi Muhammad Saw seorang mukmin terhadap mukmin lainnyan laksana suatu bangunan yang unsur-unsurnya saling menguatkan. Hal ini berarati bahwa suatu masyarakat harus hidup bergotong royang, tolong menolong, dan saling membantu. Dalam prinsip persamaan menunjukan bahwa manusia itu sama, perbedaan kebangsaan, keturunan, jenis kelamin, kekayaan dan jabatan, tidak mengubah posisi seseorang di 
hadapan Allah Swt. Perbedaan seseorang dengan yang lainnya terletak pada iman dan taqwa (IMTAQ)nya kepada Allah Swt. Dalam prinsip kemerdekaan meliputi bidang agama, politik, dan ekonomi.

Masyarakat yang toleran dan religius di lingkungan perumahan WPS mendorong berlangsungnya proses-proses dan interaksi yang lebih sejuk dan guyub. Oleh karenanya saat ini nilai-nilai persaudaraan dan keagamaan yang lebih konkret telah berkembang di perumahan WPS. Telah disepakati bahwa antar sesama warga harus bahu membahu untuk membangun semangat kebersamaan. Sementara untuk menjaga keberlangsunagan dan kesinambungan kegiatan keislaman, perlu internalisasi nilai-nilai keislaman melalui kaderisasi anak-anak di lingkungan Perumahan WPS.

Oleh karena itu, terdapat beberapa pokok pikiran penting yang perlu diwujudkan dan disepakati di WPS dalam membangun masyarakat religius yaitu: (1) pembudayaan tradisi Islam lokal dalam kehidupan masyarakat yang majemuk, 2) setiap urusan warga diselesaikan dengan semangat musyawarah, (3) Menjunjung tinggi moral dan menjalin kerjasama yang baik antar warga masyarakat. Membangun masyarakat religius dan menjalankan amaliyah Islam nusantara, harus dimotori oleh warga yang afiliasi organisasinya kepada dua ormas besar yaitu NU dan Muhammadiyah.

Dalam rangka tetap menjaga konsistensi program yang telah dicanangkan warga perumahan WPS telah ditetapkan bersama di organisasi paguyuban, tindak lanjutnya adalah dengan implemntasi mambangun semangat kebersamaan melalui kegiatan pengajian yasinan dan tahlil, serta kajian keislaman setiap malam jum'at. Selain itu untuk mewujudkan generasi yang islami dan memiliki keislaman yang kokoh didirikan lembaga madrasah diniyah yang diselenggarakan di mushalla setiap hari selain hari Sabtu dan Ahad sebagaimana yang tanpak dalam gambar di bawah ini.
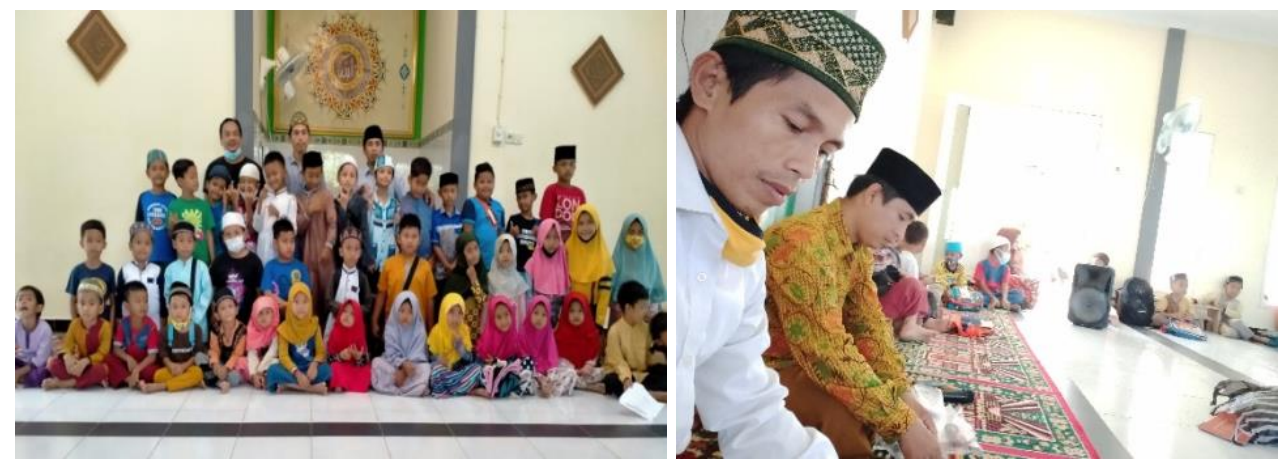

$8 \mid$ 
Gambar 2. Foto Bersama antar pengurus dengan murid-muridMadrasah Diniyah Raudlatul Muta'allimin di Perumaah WPS $e$

Ada hasil yang nayata dari pendampigan dan pembinaan yang telah dilakukan, yakni adanya kemauan dan semangat untuk berkumpul di paguyuban untuk memikirkan dan berbuat untuk kepentingan bersama dan generasi perumahan. Dari gejala yang ditimbulkan dari adanya wadah organisasi peguyuban dan Madrasah Diniyah menjadi potensi besar guna memggerakkan mereka demi mewujudkan tempat paguyuban yang agamis dan toleran di lingkungan perumahan.

Melihat potensi perumahan, sangat dimungkinkan untuk dijadikan sebagai model perumahan dengan kegiatan pendidikan dan keagamaan dalam rangka meningkatkan kemakmuran bersama, menjalankan tugas agama dan kemasyarakan. Oleh sebab itu, konsep untuk mewujudkan masyarakat yang religius maka dimusyawarahkan dengan konsep penataan dan pemetaan kegiatan dan kebutuhan masyarakat sesuai dengan tingkat ekonomi dan agamanya masinh-masing. Langkah awal paguyuban melakukan musyawarah untuk menetukan kelas madrsaah diniyah dan sarana lainnya yang dibutuhkan.

Dari upaya-upaya tersebut ada hasil perubahan, awalnya anak-anak perumahan bsetelah pulang sekolah banyak yang bermasin seperti main layangan, sepeda, saat ini mengikuti kegiatan belajar mengajar yang diselenggarakans etelah ashar. Sebagaimana yang tampak pada gambar di bawah.
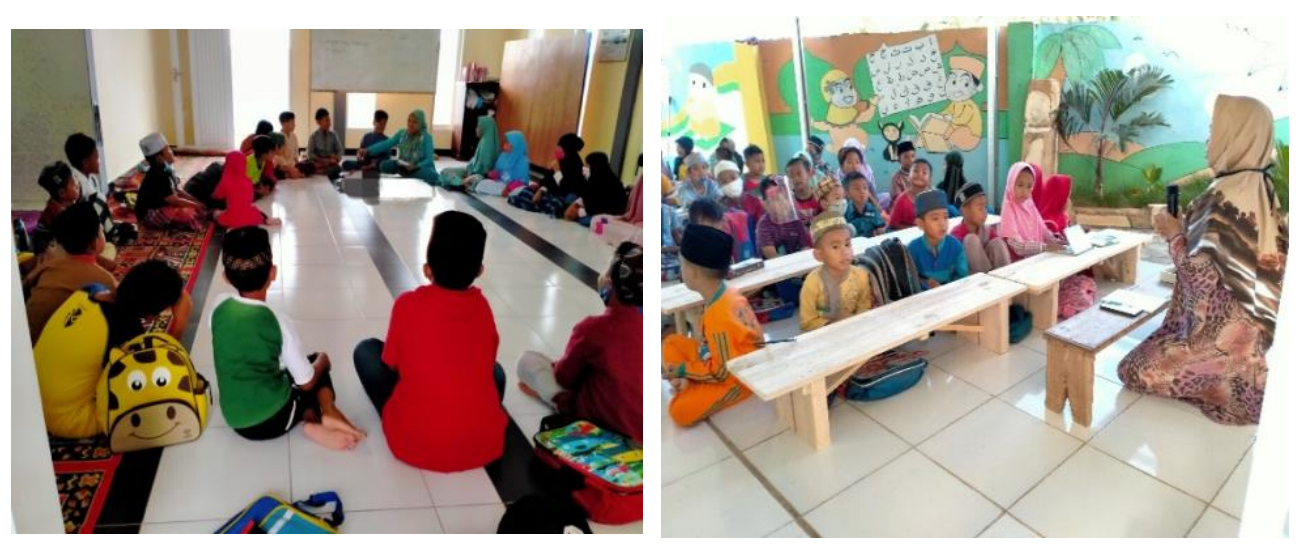
Gambar 3.Kegiatan Diniyah dan pendidikan Alquran di WPS setelah terbentuk

Gambar di atas adalah kegaiatan KBM madrasah diniyah sebagai tindak lanjut dari kebutuhan warga akan pendidikan agama. Dari kediatan tersebut, optimisme masyarat akan lahirnya generasi dan menjadi masyarakat yang agamsis, taat beragama, toleran dan guyub semakin tinggi. Adapun yang masih menjadi kendala dalam mewujudkan masyarakat religius di lingkungan Perumahan WPS diantaranya: Pertama: Kualitas SDM yang belum memadai karena latar belakang pendidikan yang beragam daminnya SDM, Kedua: Masih rendahnya pendidikan politik masyarakat, ketiga: Kondisi sosial politik yang belum pulih pasca reformasi.

\section{Kesimpulan}

Berangkat dari paparan di atas, setidaknya dapat ditarik kesimpulan dalam pendampingan yang kami lakukan, diantaranya:

1. Tebentuknya peguyuban pengajian sebagai wadah warga perumahan WPS tidak lepas dari adanya kebutuhan warga setempat dengan mengedepankan komunikasi yang baik serta keterlibatan PKM secara langsung dan berkesinambungan.

2. Didirikannya Madrasah Diniyah untuk anak-anak warga WPS yangs selama ini belum ada, tidak lepas dari dukungan warga perumahan yang sangat tinggi. Kuatnya dukungan masyarakat tidak lepas dari cara komunikasi, pendekatan interpersonal secara epatik dan tampa mengguri oleh pendamping.

3. Amaliyah Islam Nusantara seperti tahlilan, diba'an, yasinan dan sarwaan saat ini sudah mulai berkembang dan diminati warga. Terjadinya perubahan pola pergaulan masyarakat dari tindak adanya kegaitan keagamaan dan lembaga pendidikan Islam hingga didirikan berkat kesadaran dan semangat untuk membangun lingkungan yang riligius melalui sosialsasi dan internalisai nilai Islam Nusantara

4. Tercapainya tujuan diatas dan pembinaan warga WPS melalui metode partisipatoris didasarkan kepada pentingnya nilai-nilai sosaial kemasyarakatan dalam mewujudkan masyarakat religius. 


\section{Daftar Pustaka}

Sumber: Yuwono, Teguh. 2001. Manajemen Otonomi Daerah : Membangun Daerah Berdasar Paradigma Baru. Semarang: Clyapps Diponegoro University

Suryono, Agus. 2001. Teori dan Isi Pembangunan. Malang: Universitas Negeri Malang. UM Press

Supriady, Deddy dan Riyadi. 2005. Perencanaan Pembangunan Derah. Jakarta: SUN

Isbandi, Rukminto Adi. 2007. Perencanaan Partisipatoris Berbasis Aset Komunitas : Dari Pemikiran Menuju Penerapan. Depok: Fisip UI press

Handayani, Suci. 2006. Perlibatan Masyarakat Marginal Dalam Perencanaan dan Penganggaran Partisipasi (Cetakan Pertama). Surakarta: Kompip Solo

Slamet, M. 2003. Membentuk Pola Perilaku Manusia Pembangunan. Bogor: IPB Press 